\title{
GROWTH, SURVIVAL AND REPRODUCTIVE SUCCESS OF Clarias gariepinus BROODSTOCKS FED FEED MIXED WITH 17- $\alpha$-METHYL TESTOSTERONE (MT) IN STAGNANT CONCRETE SYSTEMS
}

\author{
Robert E.A ${ }^{1}$, Onyeche, V. O. ${ }^{2}$, Ovie, S.O. ${ }^{3}$, Biyontubo, O. ${ }^{4}$, Ekundayo, T. ${ }^{5}$, Offor, C.C. ${ }^{6}$ \\ ${ }^{1}$ National Institute for Freshwater Fisheries Research, New Bussa, Niger state, Nigeria; \\ ${ }^{2}$ National Institute for Freshwater Fisheries Research, New Bussa, Niger state, Nigeria; \\ ${ }^{3}$ National Institute for Freshwater Fisheries Research, New Bussa, Niger state, Nigeria; \\ ${ }^{4}$ National Institute for Freshwater Fisheries Research, New Bussa, Niger state, Nigeria; \\ ${ }^{5}$ National Institute for Freshwater Fisheries Research, New Bussa, Niger state, Nigeria; \\ ${ }^{6}$ National Institute for Freshwater Fisheries Research, New Bussa, Niger state, Nigeria; \\ Corresponding author: Robert, E. A; Email: ememrobert@gmail.com \\ DOI: $10.31364 / \mathrm{SCIRJ} / \mathrm{v} 7 . \mathrm{i} 3.2019 . \mathrm{P} 0319620$ \\ http://dx.doi.org/10.31364/SCIRJ/v7.i3.2019.P0319620
}

\begin{abstract}
The growth performance, survival and reproductive success of Clarias gariepinus broodstocks were examined as they responded to 17- $\alpha$-methyl testosterone (MT) and absolute ethanol mixed in their feed in varying levels of $50 \mathrm{mgKg}^{1} / \mathrm{MT}^{1}, 100$ $\mathrm{mgKg}^{-}{ }^{1} / \mathrm{MT}$ and $0 \mathrm{mgKg}^{-}{ }^{1} / \mathrm{MT}$. These inclusion levels also served as the three treatments TC 50, TC 100, TC 0 . A total of 24 Clarias gariepinus broodstocks were stocked in six (6) concrete stagnant systems of 4 ( 2 males, 2 females) fishes per tank of 2 metre by 2 metre square, with duplicated treatments of TC 50 and TC 100. Treatment TC 0 was also duplicated, and served as the control, with 4 fishes per tanks ( 2 males and 2 females). Duration was for ninety (90) days. The mean initial weights were taken as 2.05 $\pm 353.56 \mathrm{~g}$ for treatment TC $50,1.60 \pm 282.84 \mathrm{~g}$ for treatment TC 100 and $1.65 \pm 494.98 \mathrm{~g}$ for treatment TC 0 . Highest mean weight gain of $3.45 \pm 2.22 \mathrm{~g}$ observed in the study was seen in the Clarias gariepinus broodstock tank TC 50. Performance index showed treatment TC 50 performed highest with value $601.85 \pm 239$.09. Survival rate was high in treatment TC 50 with $50.0 \pm 0.00 \%$, higher in treatment TC 0 with $62.50 \pm 17.68 \%$ and highest in treatment TC 100 with $87.50 \pm 17.68 \%$. Condition factor $\mathrm{K}$ was greater than 1 throughout the study showing well-being of the fishes; highest in treatment TC 50 at value 7.20. Water quality parameters were at normal ranges throughout the study.
\end{abstract}

Keywords: growth, survival, reproduction, duplicates, Clarias gariepinus, broodstocks, stagnant.

\section{INTRODUCTION}

Fish is very important to a human's diet; often termed an irreplaceable source of animal based protein all over the world (Mubarik et al., 2011). The most cultured catfish species in Africa, especially in Nigeria are Clarias gariepinus (Burchell, 1822; Engle and Valderrama, 2001). This specie exhibits different feed utilization efficiencies, growth performance, and disease resistance, under different culture systems (Gamal et al., 2008).

Rearing culturable fish species under controlled environments or enclosures, has become helpful in enhancing fish supply (Afinowi and Marioghae,1986). 17- $\alpha$-methyl testosterone (MT) is reported to hormonally stimulate and enhance growth especially in male fish as it is a male androgen steroid ; with consideration for hormone dosage, treatment start time, duration and stocking density (Mubarik et al.,2011). Stimulation of male fish produces viable seed production (Oguntuase and Adebayo, 2014); yet, viability is further

www.scirj.org

(C) 2019, Scientific Research Journal

http://dx.doi.org/10.31364/SCIRJ/v7.i3.2019.P0319620 
dependent on the type of synthetic hormone used (Nwokoye et al., 2007), and the efficacy of synthetic hormones records much more hatchability and survivability in catfishes than the natural hormones (Krol et al., 2006).

The use of hormones in female catfish is popular worldwide; yet, there is little information on inducing testicular maturation in male fish (Oguntuase and Adebayo, 2014). Scarcity of male broodstocks are on the high; many of the male broodstocks are without matured testes, so the use of 17- $\alpha$-Methyl Testosterone(MT) in feed will come in handy to ascertain increase in the viability of males or not, to be used for induced breeding and their reproductive success. Much work has been done on Tilapia spp. and Cyprinus carpio using $17 \alpha$-Methyltestosterone, yet not enough on Clarias gariepinus.

\section{MATERIALS AND METHODS}

This research involved evaluating the growth, survival and reproductive success of Clarias gariepinus brooodstocks using the male steroid $17 \alpha$-MethylTestosterone with a view to determining the effectiveness of the hormone or male steroid $17 \alpha-$ MethylTestosterone or MT on Clarias gariepinus male broodstocks.

\section{Experimental fish}

Broodstocks were procured from the broodstock bank of the National Institute for Freshwater Fisheries Research (NIFFR) hatchery in New Bussa, Niger State of Nigeria and its environs. Broodstock sizes ranged from $1.3 \mathrm{~kg}-2.3 \mathrm{~kg}(1300 \mathrm{~g}-2300 \mathrm{~g})$.

\section{Experimental site}

The source of water was NIFFR'S Kigera Dam which is the Institute's source of water all year round, yet augmented with the borehole systems for the dry season. For this research, the Kigera dam's water was used.

\section{Experimental Design}

Growth, survival and reproductive success of Clarias gariepinus broodstocks were achieved by administering the hormone $17 \alpha$ MethylTestosterone mixed with absolute ethanol orally, into fish feed. This administration was in varying doses: $50 \mathrm{mg} / \mathrm{kg}$ and $100 \mathrm{mg} / \mathrm{kg}$ with the addition of $4 \mathrm{ml}$ of absolute ethanol; while the control were fed normal feed diet without the addition of $17 \alpha-$ MethylTestosterone and absolute ethanol. There were three treatments replicated two times for the main treatments and the control treatment.

These treatments were: $\mathrm{TC}_{50}, \mathrm{TC}_{100}, \mathrm{TC}_{0} . \mathrm{TC}_{50}$ and $\mathrm{TC}_{100}$ in six tanks while tanks $\mathrm{TC}_{0}$ served as the control. Fish feeding with $6 \mathrm{~mm}$ NIFFR broodstock feed were orally mixed with $17 \alpha$-MethylTestosterone and absolute ethanol poured evenly on feed, mixed and dried under room temperature for twenty four (24) hours; then carried out at 2\%, 3\%, 5\% and 5\% of the body weight of broodstocks till end of the experiment. Clarias gariepinus broodstocks were kept in $2 \mathrm{~m} \times 2 \mathrm{mx} 1 \mathrm{~m}$ tanks for the duration of this experiment, and stocking was 4 broodstocks per treatment and duplicate, totaling 24 Clarias gariepinus broodstocks used to ascertain growth, survival and reproductive success in six tanks. Experimental design was a randomized block design.

\section{Incubation and Hatching procedures}

Fertilized eggs were incubated in six (6) concrete tanks $(2 \mathrm{~m} \times 2 \mathrm{~m} \times 1 \mathrm{~m})$. Two of the first tanks contained a batch of fertilized eggs from treatment TC 50; the next two contained a batch of fertilized eggs from treatment TC 100 while the last two concrete tanks contained a batch of fertilized eggs from TC 0 which served as the control. Eggs were incubated at $\left(25^{\circ} \mathrm{c}\right)$ with he tanks continuously aerated using aerators throughout the incubation period. Hatching was concluded at 30 hours post-fertilization.

\section{Fertilization and Hatchability}

The greenish eggs mass seen in the tanks were the incubated eggs. Eggs were estimated according to Omitoyin et al., (2011). Percentage hatchability and fertilization were calculated thus:

- $\%$ Fertilization $=$

number of fertilized eggs $\times 100$ 
number of incubated eggs

(Omitoyin et al., 2011)

- $\%$ Hatchability $=$

number of hatchlings $\times 100$

number of fertilized eggs

(Oyebola and Awodiran, 2015).

\section{Growth parameters}

Growth parameters such as MIW, MFG, MWG, \%WG, SGR, CP, FCR, FCE, PI, \% Survival.

\section{Statistical Analysis}

Analysis of data for each treatment and feed were assessed and compared using ANOVA, Duncan Multiple Range Test.

- $\quad$ Survival Rate $(\mathrm{SR})=$ number of fish stocked - number of mortalities (Paschal et al., 2006).

- $\%$ Survival $=$

number of broodstock survivors at the end of study $\times 100$

number of juveniles stocked at the beginning of the study

(Coulibaly et al., 2007).

- $\quad$ Specific Growth Rate \% day (SGR)

$=\underline{\log _{\underline{n}}}$ final weight $-\log _{\underline{n}}$ initial weight $\times 100$

$$
\text { time (days) }
$$

(Benedict et al., 2005).

- $\quad \mathrm{FCR}=$ Total weight of dry feed offered / Total weight gain (Sveier et al., 2000 ).

- $\quad \mathrm{FCE}$

$=\quad$ Final weight by fish $\times 100$

Weight of feed given

(Tboujard et al., 2002).

- $\quad$ Performance Index

$\mathrm{PI}=$ Survival rate $\mathrm{X}$ Final mean weight $(\mathrm{g})$ - Initial mean body weight $(\mathrm{g})$

Rearing duration in days

(Engle and Valderrama, 2001).

www.scirj.org

(C) 2019, Scientific Research Journal

http://dx.doi.org/10.31364/SCIRJ/v7.i3.2019.P0319620 


\section{Water Quality parameters}

Water quality parameters carried out for this research were: Water Temperature, Air Temperature, DO, pH, Conductivity, Total Dissolved Solids.

\section{Experimental duration}

Duration for this experiment was 90 days and partial sampling carried out till end of the research.

\section{RESULTS}

Table 1a

THE RESULT OF PROXIMATE ANALYSIS ON 6MM NIFFR FEED SAMPLE USED

\begin{tabular}{|l|l|l|l|l|l|l|l|}
\hline S/N & ID & $\begin{array}{l}\text { \%MOISTURE } \\
\text { CONTENT }\end{array}$ & $\begin{array}{l}\text { \% ASH } \\
\text { CONTENT }\end{array}$ & $\begin{array}{l}\text { \% } \\
\text { CRUDE } \\
\text { FIBRE }\end{array}$ & $\begin{array}{l}\text { \%CRUDE } \\
\text { PROTEIN }\end{array}$ & $\begin{array}{l}\text { \% } \\
\text { CRUDE } \\
\text { FAT }\end{array}$ & \%NFE \\
\hline $\begin{array}{l}\text { NIFFR } \\
\text { FEED } \\
\text { GMM }\end{array}$ & 3.118 & 8.307 & 4.338 & 42.891 & 5.588 & 35.758 \\
& $\begin{array}{l}\text { NIFFR } \\
\text { FEED } \\
\text { 6MM }\end{array}$ & 3.076 & 7.645 & 5.021 & 43.843 & 6.021 & 33.894 \\
\hline $\begin{array}{l}\text { NIFFR } \\
\text { FEED } \\
\text { MM }\end{array}$ & 3.645 & 7.134 & 4.124 & 43.924 & 5.711 & 35.462 \\
\hline
\end{tabular}

Table 1b

THE RESULT OF PROXIMATE ANALYSIS ON 6MM NIFFR FEED MIXED WITH 17-ALPHA-METHYL TESTOSTERONE (MT)

\begin{tabular}{|c|c|c|c|c|c|c|c|}
\hline $\mathbf{S} / \mathbf{N}$ & ID & $\begin{array}{l}\% \\
\text { MOISTURE } \\
\text { CONTENT }\end{array}$ & $\begin{array}{l}\% \text { ASH } \\
\text { CONTENT }\end{array}$ & $\begin{array}{l}\% \text { CRUDE } \\
\text { FIBRE }\end{array}$ & $\begin{array}{l}\% \text { CRUDE } \\
\text { PROTEIN }\end{array}$ & $\begin{array}{l}\text { \% CRUDE } \\
\text { FAT }\end{array}$ & $\% \mathrm{NFE}$ \\
\hline TC 50 & $\begin{array}{l}\text { NIFFR } \\
\text { FEED } \\
6 \mathrm{MM}\end{array}$ & $\begin{array}{l}2.713 \\
3.100\end{array}$ & $\begin{array}{l}8.721 \\
8.337\end{array}$ & $\begin{array}{l}4.225 \\
4.192\end{array}$ & $\begin{array}{l}44.264 \\
44.517\end{array}$ & $\begin{array}{l}5.962 \\
6.148\end{array}$ & $\begin{array}{l}34.115 \\
33.706\end{array}$ \\
\hline TC 100 & $\begin{array}{l}\text { NIFFR } \\
\text { FEED } \\
6 \mathrm{MM}\end{array}$ & $\begin{array}{l}2.185 \\
2.316\end{array}$ & $\begin{array}{l}9.15 \\
8.885\end{array}$ & $\begin{array}{l}4.331 \\
4.414\end{array}$ & $\begin{array}{l}43.280 \\
43.530\end{array}$ & $\begin{array}{l}6.236 \\
6.310\end{array}$ & $\begin{array}{l}34.818 \\
34.545\end{array}$ \\
\hline TC O & $\begin{array}{l}\text { NIFFR } \\
\text { FEED } \\
6 \mathrm{MM}\end{array}$ & $\begin{array}{l}2.194 \\
2.348\end{array}$ & $\begin{array}{l}8.818 \\
8.264\end{array}$ & $\begin{array}{l}4.174 \\
3.962\end{array}$ & $\begin{array}{l}42.588 \\
42.693\end{array}$ & $\begin{array}{l}6.224 \\
5.981\end{array}$ & $\begin{array}{l}36.002 \\
36.752\end{array}$ \\
\hline $\begin{array}{l}\text { SEM } \pm \text { ST } \\
\text { D }\end{array}$ & & $3.27 \pm 0.31$ & $7.69 \pm 0.58$ & $4.49 \pm 0.46$ & $43.55 \pm 0.57$ & $5.77 \pm 0.22$ & $35.03 \pm 1.00$ \\
\hline
\end{tabular}


Table 2

THE RESULT OF STATISTICAL ANALYSIS ON 6MM NIFFR FEED MIXED WITH 17-ALPHA-METHYL TESTOSTERONE (MT)

\begin{tabular}{|c|c|c|c|c|c|c|c|}
\hline $\mathbf{S} / \mathbf{N}$ & ID & $\begin{array}{l}\% \\
\text { MOISTURE } \\
\text { CONTENT }\end{array}$ & $\begin{array}{l}\% \\
\text { ASH } \\
\text { CONTENT }\end{array}$ & $\begin{array}{l}\% \\
\text { CRUDE } \\
\text { FIBRE }\end{array}$ & $\begin{array}{l}\% \\
\text { CRUDE } \\
\text { PROTEIN }\end{array}$ & $\begin{array}{l}\text { \% } \\
\text { CRUDE FAT }\end{array}$ & $\%$ NFE \\
\hline TC 50 & $\begin{array}{l}\text { NIFFR } \\
\text { FEED } \\
6 \mathrm{MM}\end{array}$ & $2.906 \pm 0.27^{\mathrm{b}}$ & $8.529 \pm 0.27^{\mathrm{a}}$ & $4.208 \pm 0.02^{\mathrm{a}}$ & $44.390 \pm 0.1^{\mathrm{c}}$ & $6.055 \pm 0.13^{\mathrm{a}}$ & $33.910 \pm 0.28^{\mathrm{a}}$ \\
\hline TC 100 & $\begin{array}{l}\text { NIFFR } \\
\text { FEED } \\
6 \mathrm{MM} \\
\end{array}$ & $2.250 \pm 0.07^{\mathrm{a}}$ & $9.017 \pm 0.15^{\mathrm{b}}$ & $4.372 \pm 0.04^{\mathrm{b}}$ & $43.405 \pm 0.14^{\mathrm{b}}$ & $6.273 \pm 0.04^{\mathrm{b}}$ & $34.681 \pm 0.15^{b}$ \\
\hline TC O & $\begin{array}{l}\text { NIFFR } \\
\text { FEED } \\
6 \mathrm{MM}\end{array}$ & $2.271 \pm 0.08^{\mathrm{a}}$ & $8.541 \pm 0.30^{\mathrm{a}}$ & $4.068 \pm 0.11^{\mathrm{a}}$ & $42.640 \pm 0.05^{\mathrm{a}}$ & $6.102 \pm 0.13^{\mathrm{a}, \mathrm{b}}$ & $36.377 \pm 0.41^{c}$ \\
\hline $\begin{array}{l}\mathrm{SEM} \pm \mathrm{ST} \\
\mathrm{D}\end{array}$ & & 0.07 & 0.09 & 0.04 & 0.19 & 0.03 & 0.31 \\
\hline
\end{tabular}

Means in the same column (for each section) with different superscript are statistically different $(\mathrm{p}<0.05)$. 
Table 3

PERCENTAGE OF Clarias gariepinus BROODSTOCKS' REPRODUCTIVE SUCCESS WHEN FED FEED MIXED WITH $17 \alpha$-METHYLTESTOSTERONE (MT)

\begin{tabular}{|c|c|c|}
\hline Treatments & Sterility\% & Fry \% \\
\hline TC 50 & $0.00^{\mathrm{a}}$ & $82.05^{a}$ \\
\hline TC 100 & $0.00^{b}$ & $74.01^{b}$ \\
\hline TC 0 & $40.00^{c}$ & $54.0^{c}$ \\
\hline
\end{tabular}

Table 4

GROWTH PERFORMANCE OF Clarias gariepinus BROODSTOCKS FED FEED MIXED WITH $17 \alpha$-METHYLTESTOSTERONE (MT) IN STAGNANT CONCRETE SYSTEMS

\begin{tabular}{|c|c|c|c|c|c|c|c|c|c|}
\hline Tanks & MIW (g) & MFW (g) & MWG (g) & $\% \mathrm{WG}$ & SGR (\%) & SR (\%) & FCR & FCE & PI \\
\hline TC 50 & $2.05 \pm 353.56^{\mathrm{a}}$ & $3.47 \pm 35.36^{\mathrm{b}}$ & $3.45 \pm 31.43^{\mathrm{a}}$ & $55.15 \pm 21.49^{b}$ & $0.258 \pm 0.07^{\mathrm{a}}$ & $50.0 \pm 0.00^{\mathrm{a}}$ & $0.143 \pm 0.00^{\mathrm{a}}$ & $4.97 \pm 0.07^{\mathrm{a}}$ & $601.85 \pm 239.09^{\mathrm{a}}$ \\
\hline TC 100 & $1.60 \pm 282.84^{\mathrm{a}}$ & $2.30 \pm 282.84^{\mathrm{a}}$ & $2.28 \pm 279.70^{\mathrm{b}}$ & $28.10 \pm 15.16^{\mathrm{a}}$ & $0.177 \pm 0.02^{\mathrm{a}}$ & $87.50 \pm 17.68^{\mathrm{a}}$ & $0.058 \pm 0.06^{\mathrm{b}}$ & $3.09 \pm 0.887^{\mathrm{a}}$ & $458.33 \pm 215.61^{\mathrm{a}}$ \\
\hline TC O & $1.65 \pm 494.98^{\mathrm{a}}$ & $2.39 \pm 1428.36^{\mathrm{a}}$ & $2.37 \pm 1422.86^{b}$ & $48.81 \pm 14.48^{\mathrm{a}, \mathrm{b}}$ & $0.142 \pm 0.16^{\mathrm{a}}$ & $62.50 \pm 17.68^{\mathrm{a}}$ & $0.153 \pm 0.24^{\mathrm{c}}$ & $5.01 \pm 1.78^{\mathrm{a}}$ & $759.72 \pm 216.27^{\mathrm{a}}$ \\
\hline SEM & 152.02 & 357.40 & 355.91 & 6.45 & 0.03 & 8.33 & 0.04 & 0.63 & 77.92 \\
\hline
\end{tabular}

Means in the same column (for each section) with different superscript are statistically different $(\mathrm{p}<0.05)$.

Treatments: ${ }^{1}$ TC 50 Treatment Clarias gariepinus fed $50 \mathrm{mgKg}_{-}{ }^{1}$ of $17 \alpha$-MethylTestosterone $\left(50 \mathrm{mgKg}-{ }^{1} / \mathrm{MT}\right)$ in feed

${ }^{2}$ TC 100 Treatment Clarias gariepinus fed $100 \mathrm{mgKg}_{-}{ }^{1}$ of $17 \alpha-$ MethylTestosterone $\left(100 \mathrm{mgKg}_{-}{ }^{1} / \mathrm{MT}\right)$ in feed

${ }^{3}$ TC 0 Treatment Clarias gariepinus fed $0 \mathrm{mgKg}_{-}{ }^{1}$ of $17 \alpha$-MethylTestosterone $\left(0 \mathrm{mgKg}-{ }^{1} / \mathrm{MT}\right)$ in feed 
Table 5

MORPHOMETRIC MEASUREMENTS AND CONDITION FACTOR OF Clarias gariepinus BROODSTOCKS FED FEED MIXED WITH $17 \alpha$-METHYLTESTOSTERONE (MT) IN STAGNANT CONCRETE SYSTEMS

\begin{tabular}{|l|l|l|l|l|}
\hline $\begin{array}{l}\text { SPECIES/ } \\
\text { TREATMENTS/MAX/MIN } \\
\text { VALUES }\end{array}$ & $\begin{array}{l}\text { TOTAL } \\
\text { LENGTH }(\mathbf{c m}) \\
\text { Clarias gariepinus }\end{array}$ & $\begin{array}{l}\text { STANDARD } \\
\text { LENGTH }(\mathbf{c m})\end{array}$ & WEIGHT (g) & $\begin{array}{l}\text { CONDITION } \\
\text { FACTOR (K) }\end{array}$ \\
\hline TC 50 & & & & \\
\hline Min & 109.5 & & & \\
\hline Max & 121.25 & 96.75 & 2050 & 5.15 \\
\hline Mean \pm SEM & $115.25 \pm 2.42^{\mathrm{b}}$ & 107.5 & 3475 & 7.20 \\
\hline & & $101.8 \pm 2.21^{\mathrm{b}}$ & $286.5 \pm 322.82^{\mathrm{a}}$ & $6.18 \pm 0.01^{\mathrm{a}}$ \\
\hline TC 100 & & & \\
\hline Min & 88.7 & & & \\
\hline Max & 110.75 & 79.75 & 1600 & 3.13 \\
\hline Mean \pm SEM & $102.17 \pm 4.74^{\mathrm{a}}$ & 99.5 & 2300 & 5.28 \\
\hline TC 0 & & & $193.25 \pm 147.68^{\mathrm{a}}$ & $4.18 \pm 0.03^{\mathrm{a}}$ \\
\hline Min & & & & \\
\hline Max & 101.5 & 91.5 & 1650 & 3.14 \\
\hline Mean \pm SEM & 122 & 106.5 & 2700 & 5.39 \\
\hline
\end{tabular}

Means in the same column (for each section) with different superscript are statistically different $(\mathrm{p}<0.05)$.

Treatments: ${ }^{1}$ TC 50 Treatment Clarias gariepinus fed $50 \mathrm{mgKg}^{-1}$ of $17 \alpha$-MethylTestosterone $\left(50 \mathrm{mgKg}-{ }^{1} / \mathrm{MT}\right)$ in feed ${ }^{2} \mathrm{TC} 100$ Treatment Clarias gariepinus fed $100 \mathrm{mgKg}-^{1}$ of $17 \alpha$-MethylTestosterone $\left(100 \mathrm{mgKg}-{ }^{1} / \mathrm{MT}\right)$ in feed ${ }^{3} \mathrm{TC}_{0}$ Treatment Clarias gariepinus fed $0 \mathrm{mgKg}_{-}{ }^{1}$ of $17 \alpha$-MethylTestosterone $\left(0 \mathrm{mgKg}_{-}{ }^{1} / \mathrm{MT}\right)$ in feed

Table 6

LENGTH-WEIGHT RELATIONSHIP REGRESSION OF Clarias gariepinus BROODSTOCKS FED FEED MIXED WITH $17 \alpha$-METHYLTESTOSTERONE (MT) IN STAGNANT CONCRETE SYSTEMS

Specie/Treatments/SL/TL

Intercept

(a)
Growth pattern

(b)
Coefficient of determination $\mathbf{R}^{2}$

\section{Clarias gariepinus}

Standard length $(\mathrm{cm})$

TC 50

TC 100

TC 0

Total length (cm)

TC 50

7.58

5.35

1.98 


\section{TC 100}

TC 0

Treatments: ${ }^{1}$ TC 50 Treatment Clarias gariepinus fed $50 \mathrm{mgKg}-^{1}$ of $17 \alpha$-MethylTestosterone $\left(50 \mathrm{mgKg}-{ }^{1} / \mathrm{MT}\right)$ in feed ${ }^{2}$ TC 100 Treatment Clarias gariepinus fed $100 \mathrm{mgKg}-^{1}$ of $17 \alpha$-MethylTestosterone $\left(100 \mathrm{mgKg}_{-}{ }^{1} / \mathrm{MT}\right)$ in feed ${ }^{3} \mathrm{TC}_{0}$ Treatment Clarias gariepinus fed $0 \mathrm{mgKg}_{-}{ }^{1}$ of $17 \alpha$-MethylTestosterone $\left(0 \mathrm{mgKg}_{-}{ }^{1} / \mathrm{MT}\right)$ in feed

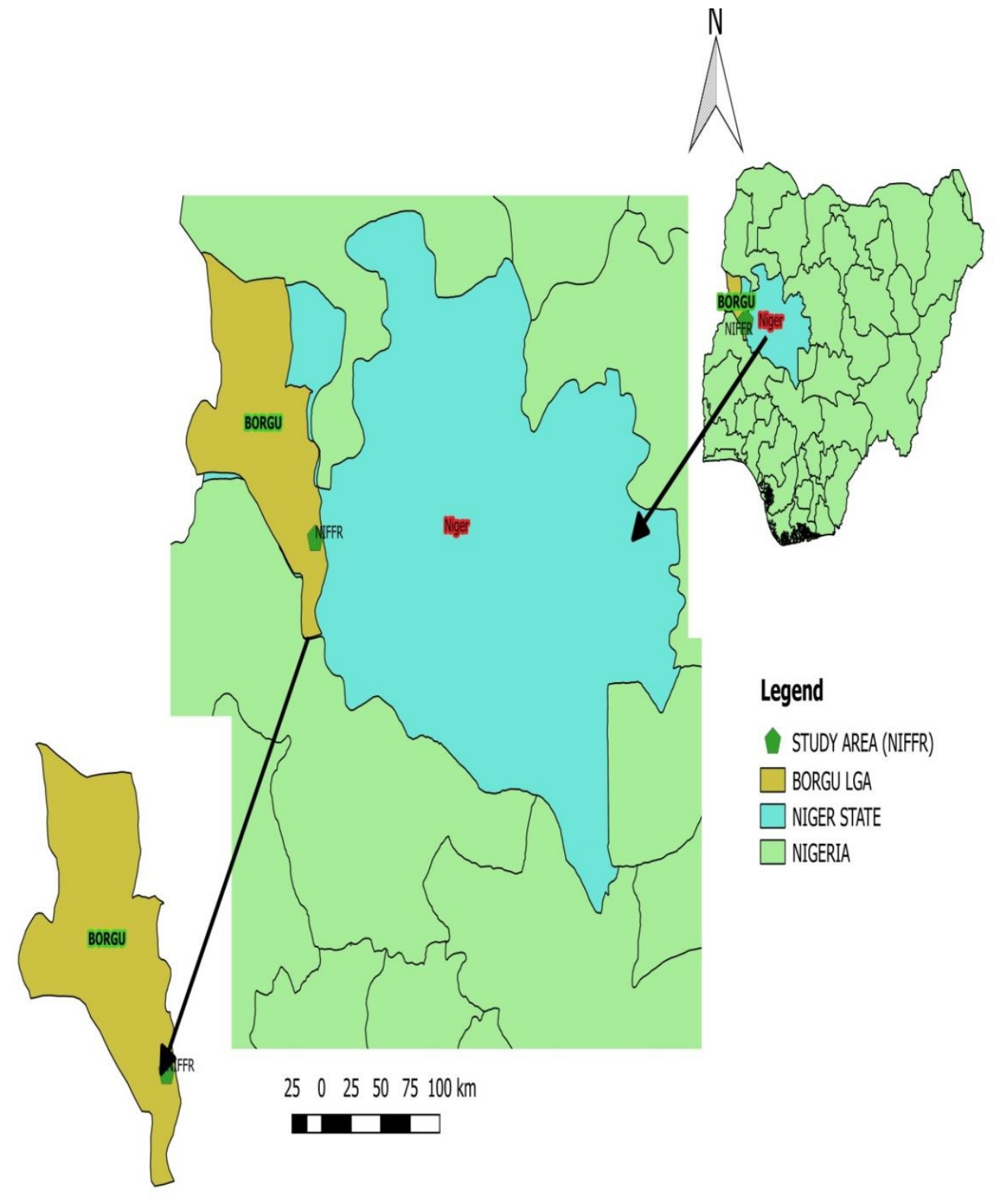

Source: NIFFR Archives, (2015) and Robert et al., (2019a)

Figure I: Map of Borgu Local Government Area with headquarters at New Bussa 


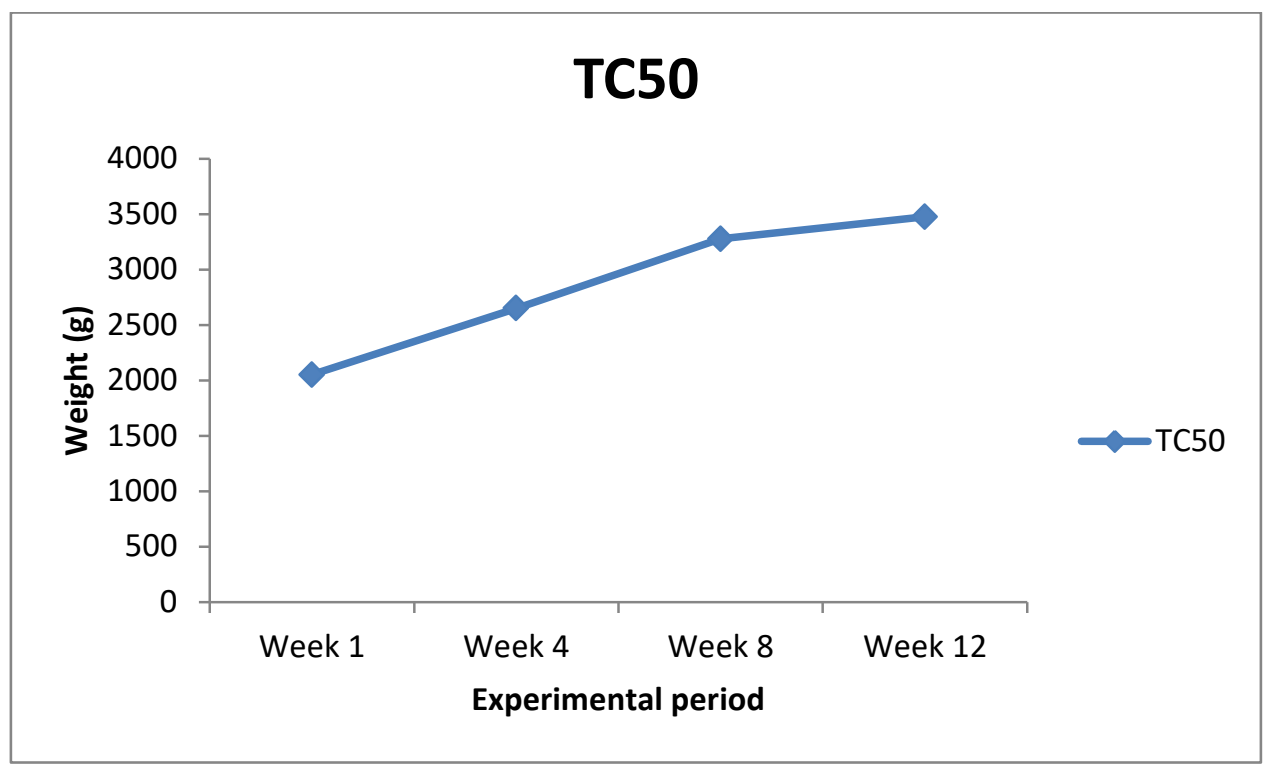

Figure 2: Growth patterns of Clarias gariepinus broodstocks fed feed mixed with $17 \alpha$-MethylTestosterone in stagnant concrete systems

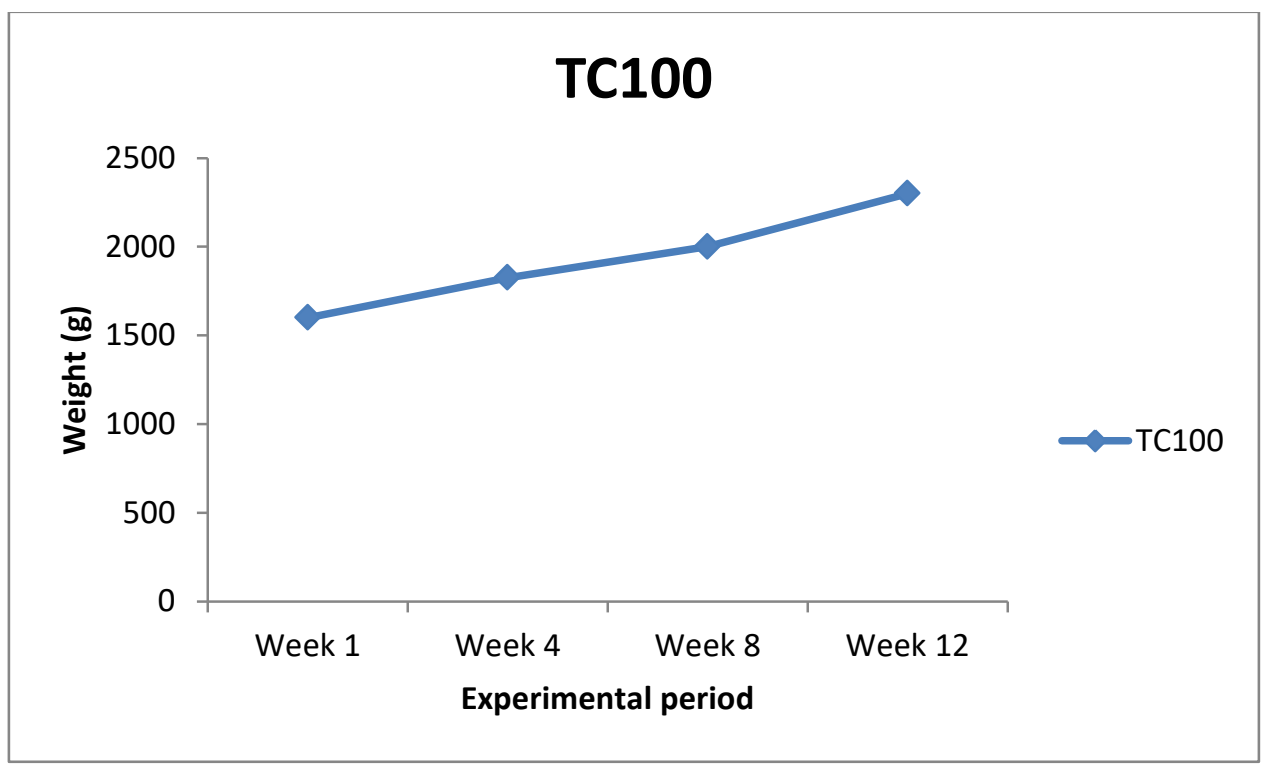

Figure 3: Growth patterns of Clarias gariepinus broodstocks fed feed mixed with $17 \alpha$-MethylTestosterone in stagnant concrete systems 


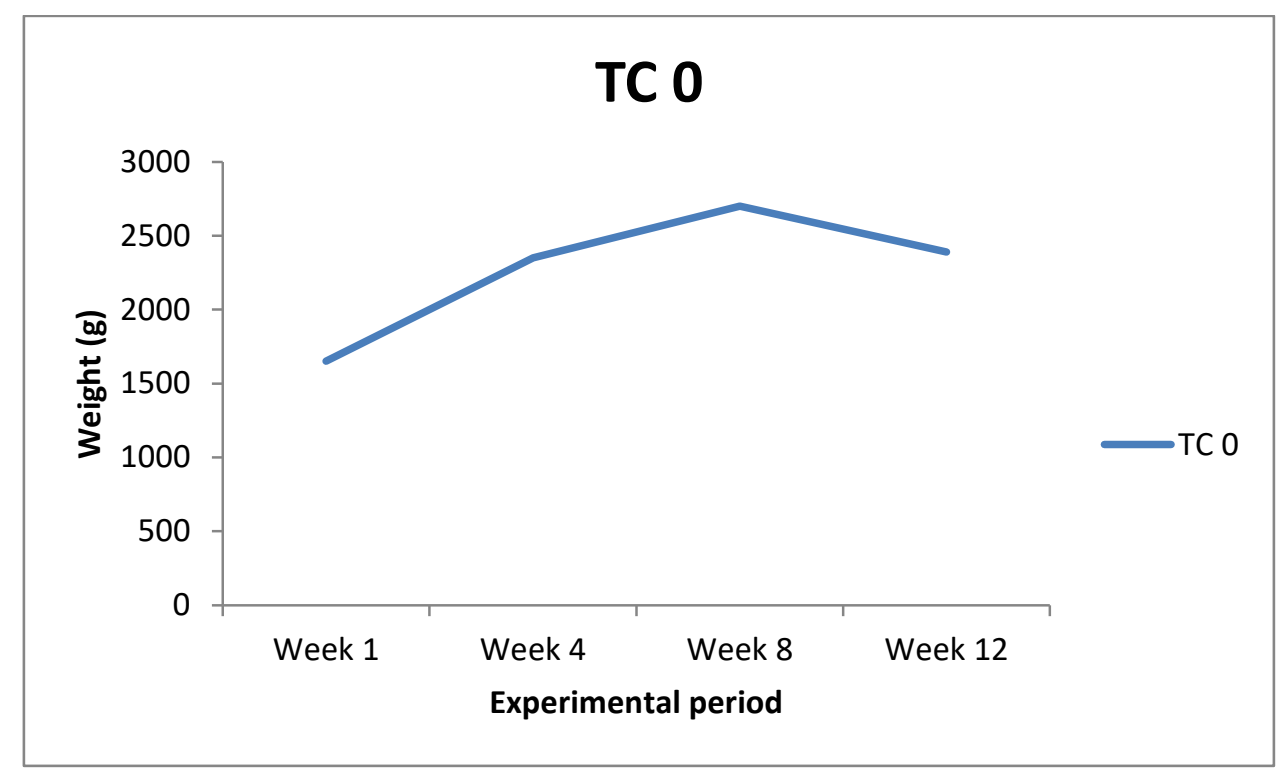

Figure 4: Growth patterns of Clarias gariepinus broodstocks fed feed mixed with $17 \alpha$-MethylTestosterone in concrete stagnant systems

Table 7

WATER QUALITY PARAMETERS OF Clarias gariepinus BROODSTOCKS FED FEED MIXED WITH 17 METHYLTESTOSTERONE (MT) IN STAGNANT CONCRETE SYSTEMS

\begin{tabular}{|l|l|l|l|}
\hline \multirow{2}{*}{ Water quality parameters } & \multicolumn{3}{|c|}{ Treatments } \\
\cline { 2 - 4 } & TC 50 & TC 100 & TC 0 \\
\hline pH & $7.37 \pm 0.26^{\mathrm{a}}$ & $7.25 \pm 0.12^{\mathrm{a}}$ & $7.4 \pm 0.16^{\mathrm{a}}$ \\
\hline DO $(\mathbf{m g} / \mathbf{l})$ & $5.3 \pm 0.46^{\mathrm{a}}$ & $5.35 \pm 0.56^{\mathrm{a}}$ & $6.12 \pm 0.81^{\mathrm{a}}$ \\
\hline CONDUCT $(\boldsymbol{\mu S} / \mathbf{c m})$ & $27.5 \pm 17.07^{\mathrm{a}}$ & $46.25 \pm 17.97^{\mathrm{a}}$ & $52.5 \pm 44.25^{\mathrm{a}}$ \\
\hline TDS $(\mathbf{m g} / \mathbf{l})$ & $13.22 \pm 8.21^{\mathrm{a}}$ & $22.22 \pm 8.64^{\mathrm{a}}$ & $25.23 \pm 21.27^{\mathrm{a}}$ \\
\hline AIR TEMP $\left({ }^{\circ} \mathbf{c}\right)$ & $24.35 \pm 1.66^{\mathrm{a}}$ & $24.35 \pm 1.66^{\mathrm{a}}$ & $24.35 \pm 1.66^{\mathrm{a}}$ \\
\hline WATER TEMP $\left({ }^{\circ} \mathbf{c}\right)$ & $27.47 \pm 1.41^{\mathrm{a}}$ & $27.47 \pm 1.41^{\mathrm{a}}$ & $27.47 \pm 1.41^{\mathrm{a}}$ \\
\hline
\end{tabular}

Means in the same column (for each section) with different superscript are statistically different $(\mathrm{p}<0.05)$.

Treatments: ${ }^{1}$ TC 50 Treatment Clarias gariepinus fed $50 \mathrm{mgKg}_{-}{ }^{1}$ of $17 \alpha$-MethylTestosterone $\left(50 \mathrm{mgKg-}{ }^{1} / \mathrm{MT}\right)$ in feed ${ }^{2}$ TC 100 Treatment Clarias gariepinus fed $100 \mathrm{mgKg}_{-}{ }^{1}$ of $17 \alpha$-MethylTestosterone $\left(100 \mathrm{mgKg}_{-}{ }^{1} / \mathrm{MT}\right)$ in feed ${ }^{3}$ TC 0 Treatment Clarias gariepinus fed $0 \mathrm{mgKg}_{-}{ }^{1}$ of $17 \alpha$-MethylTestosterone $\left(0 \mathrm{mgKg}_{-}{ }^{1} / \mathrm{MT}\right)$ in feed.

\section{DISCUSSION}

Growth Performance of Clarias gariepinus broodstocks fed feed mixed with $17 \alpha$ - methyltestosterone (MT) in concrete stagnant systems

Clarias gariepinus male and female broodstocks had initial weights ranging from $1.60 \mathrm{~g}$ to $2.05 \mathrm{~g}$. Fish fed with MT are known to show improved growth than non-treated fish (Mocintosh et al., 1985 and Marjani et al., 2009). In this experiment, fish fed with MT 
showed improved growths, thereby agreeing with Mocintosh et al.,(1985) and Marjani et al., (2009).There was no significant difference $(\mathrm{p}<0.05)$ among the treatments for MIW.

The lowest mean final weight was observed in treatment TC 100 tank. A number of mortalities occurred in week one, week two, week four, week five and week eleven. These mortalities were due to cannibalism, and the fight for survival in the tanks in weeks one, two, four and five; mortalities in the tanks for week eleven occurred due to environmental heat. As a measure, fresh water was added to the tanks to reduce heat in the tanks. Highest mean final weight was observed in the treatment tank TC 50. It is therefore suggested that the mean final weight in this study were similar in treatments TC 100, TC 0; while not similar in treatment tank TC 50. Mubarik et al., (2011) reported final weight for Cyprinus carpio, for 281 days fed with MT in concentration or inclusion level of $50 \mathrm{mgKg}{ }^{1} / \mathrm{MT}$ (T50) as $653.9 \mathrm{~g}$ and $738.1 \mathrm{~g}$ for MT inclusion level of $100 \mathrm{mgKg}^{-}{ }^{1} / \mathrm{MT}$. Mean Final weight in this study stood at $3.47 \mathrm{~g}$ for $50 \mathrm{mgKg}{ }^{1}$

/MT and $2.30 \mathrm{~g}$ for $100 \mathrm{mgKg}^{-}{ }^{1} / \mathrm{MT}$ fed twice daily. There was no significant difference between treatment TC 100 , TC 0 ; yet, there was a significant difference between treatment TC 50 and TC 100.

The Specific growth rate (SGR \%) observed in this study showed highest values for TC 50. This means the fish responded to the feed better than the other treatments. However, SGR values in this study were lower than those reported by Mubarik et al., (2011). Mubarik et al., (2011) reported SGR for Cyprinus carpio, for 281 days fed with MT in concentration or inclusion level of 50 mgKg- ${ }^{1}$ /MT (T50) as $0.572 \%$ and $0.586 \%$ for MT inclusion level of $100 \mathrm{mgKg}^{-1}$ /MT. There was no significant difference among the treatments.

Percentage Survival (\% survival) values in this study were highest for TC 100. Marjani et al., (2009) however reported highest values of survival rate of Tilapia Oreochromis niloticus fed for 21 days with MT in concentration $50 \mathrm{mgKg}_{-}{ }^{1} / \mathrm{MT}$ as $100 \%$, while for concentration $100 \mathrm{mgKg}^{-}{ }^{1} / \mathrm{MT}, 92.48 \%$.The control tanks recorded a 100\% survival rate. Mubarik et al., (2011) also recorded values of $100 \%$ survival for control tanks fed without MT, T 50 tanks fed with $50 \mathrm{mgKg}_{-}{ }^{1} / \mathrm{MT}$ mixed with feed and T 100 tanks fed with $100 \mathrm{mgKg}^{-1} / \mathrm{MT}$ mixed with feed. This attests to Clarias gariepinus' ability to withstand disease and survive under any culture system (Viveen et al.,1985). Percentage Survival showed no significant difference among the treatments.

Food conversion ratio as seen on Table 4 depicts Clarias gariepinus broodstocks used less feed to gain more weight. The results of the study for FCR corroborate the results for the study conducted by Mubarik et al., (2011) which stated similar, yet lower FCR values of 0.020 for T 50 tanks fed with $50 \mathrm{mgKg}_{-}{ }^{1} / \mathrm{MT}$ mixed with feed and 0.009 for T 100 tanks fed with $100 \mathrm{mgKg}-{ }^{1} / \mathrm{MT} \mathrm{mixed}^{2}$ with feed. Mubarik et al., (2011)'s result showed Cyprinus carpio fingerlings use even lesser feed to gain more weight. There was evidence of significant difference between treatment TC 50, TC 100; and significant difference between treatment TC 100 , TC 0.

Feed conversion efficiency (FCE) also seen on Table 4 shows highest FCE in treatment TC 0.This means treatment TC 0 were excellent at feed conversion compared to all the treatments. Ndome et al., (2011) and Robert et al., (2019a) suggested that FCE values are always a reflection of FCR values. Robert et al., (2019a) established highest value of 14.92 were seen in the stagnant control tanks in an experiment to test for the growth of monosex cultured Heterobranchus longifilis juveniles in concrete flow-through and stagnant water systems. There was no significant difference among the treatments.

Performance Index (PI) in this study were highest in treatment TC 0, compared to the study conducted by Robert et al., (2019a) which showed highest PI in stagnant tanks of the study as 7.95 and 6.08 respectively. This also proves Clarias gariepinus' ability to thrive under any condition, desirable or not (Viveen et al., 1985). Performance Index showed no significant difference among the treatments.

\section{Morphometric measurements and Condition factor of Clarias gariepinus broodstocks fed feed mixed with 17 - methyltestosterone (MT)}

The morphometric measurements and condition factor of Clarias gariepinus broodstocks are seen on Table 5 show minimum and maximum weights for treatment TC 50 as ranging from 2.05 to $3.47 \mathrm{~g}$, TC 100 weights as ranging from 1.60 to $2.30 \mathrm{~g}$ and $\mathrm{TC} 0$ weights as ranging from 1.65 to $2.70 \mathrm{~g}$. There was no significant difference between the treatments in terms of weight.

Total length depicted minimum and maximum values of $109.5 \mathrm{~cm}$ and $121.25 \mathrm{~cm}$ for TC 50 ' TC 100 showed minimum and maximum values in total length of $88.7 \mathrm{~cm}$ and $110.75 \mathrm{~cm}$; while TC 0 showed minimum and maximum values of $101.2 \mathrm{~cm}$ and $122 \mathrm{~cm}$. There was no significant difference in total length among the treatments.

www.scirj.org

(C) 2019, Scientific Research Journal

http://dx.doi.org/10.31364/SCIRJ/v7.i3.2019.P0319620 
Standard length emphasized minimum and maximum values of $96.75 \mathrm{~cm}$ and $107.5 \mathrm{~cm}$ for TC 50 ' TC 100 showed minimum and maximum values in total length of $79.75 \mathrm{~cm}$ and $99.5 \mathrm{~cm}$; while TC 0 showed minimum and maximum values of $91.5 \mathrm{~cm}$ and $106.5 \mathrm{~cm}$. There was no significant difference in total length also, among the treatments.

Condition factor K for treatment TC 50 showed minimum and maximum values of 5.15 and 7.20 , TC 100 also showed minimum and maximum values of 3.13 and 5.28; while TC 0 depicted minimum and maximum values of 3.14 and 5.39. Condition factor $\mathrm{K}$ in this study showed values greater than 1, emphasizing that the fishes were in a state of well-being. This result agrees with (Chandra and Jhan 2010; Robert et al., 2019a) who stated in their previous studies that fishes in states of well-being should show higher condition factors K of between 1.05 to 1.89 . Condition factor K, reported in a study by Robert et al., (2019a) showed condition factor of between 1.0 to 2.42. The values in this study reported Condition factor values as being in the region of 3.13 to 7.20. There was no significant difference in terms of Condition Factor $\mathrm{K}$, for all the treatments in this study.

Growth patterns of Clarias gariepinus broodstocks fed feed mixed with $17 \alpha$-methyltestosterone (MT) in stagnant concrete systems

When the b-value is less than 3, the fish is said to have negative allometric growth. When the b-value is more than 3, the fish exhibits positive allometric growth. But when the b-value is equal to 3, the fish is said to grow isometrically (Khairenizam and Norma-Rashid, 2002; Robert et al.,2019a).

The b-value in this study reveals for TC 50 values 4.68 to 5.35 indicating that the fishes for TC 50 grew positively allometric. TC 100 revealed b-values such as: 2.11 to 2.17 indicating the fishes grew negatively allometric; while TC 0 revealed b-values such as: 1.44 to 1.73 indicating the fishes grew negatively allometric as well.

The growth patterns shown in figure 2 for treatment TC 50 clearly highlights fast and progressive growth from stocking to the eighth week before dipping slightly and continuing slowly till end of the experiment.

Treatment TC 100 as shown in figure 3 highlights slow-growth from stocking; yet progresses steadily till end of the experiment.

Treatment TC 0 on the other hand, grew fastest from stocking, progressing throughout the weeks but dipped immensely from week eight till end of the experiment.

Length-weight relationship regression of Clarias gariepinus broodstocks fed feed mixed with $17 \alpha$ - methyltestosterone (MT) in stagnant concrete systems

Coefficient of determination $\left(\mathrm{R}^{2}\right)$ results on Table 6 from this study have indicated values for regression as follows: TC50 1.71-1.98, TC100 0.81-0.90, TC0 0.61-0.86. These values highlighted highest values for Coefficient of determination as $\left(\mathrm{R}^{2}\right)$ in treatment TC 50, with closely similar values for TC 100 and TC 0 .

Coefficient of determination $\left(\mathrm{R}^{2}\right)$ results in this study revealed highest values for TC 50 indicating the strongest regression in the study, followed by TC 100 with a strong regression while TC 0 showed also a strong regression similar to TC 100 .

Strong Coefficient of determination $\left(\mathrm{R}^{2}\right)$ results should be from 0.5 and more (Davies et al., 2013; Robert et al., 2019a). Robert et al., (2019a) also reported strong values for regression in their study as 0.85 for females, 0.85 for males and 0.84 for mixed sex Heterobranchus longifilis juveniles in monosex culture.

\section{Water quality parameters of Clarias gariepinus broodstocks fed feed mixed with $17 \alpha$-methyltestosterone (MT) in stagnant concrete systems}

The water quality parameters in the study presented on Table 7, showed non-significant difference throughout the treatments for $\mathrm{pH}$, DO, Conductivity, Total Dissolved Solids, Air temperature and Water temperature. 
$\mathrm{pH}$ values in this study ranged from 7.37-7.4 for treatments TC 50, TC $100, \mathrm{TC} 0$. These values were within range for freshwater fish culture. Boyd and Lichtkoppler (1979) stated ideal pH range of 6.7 to 8.6. Robert et al., (2019a) also stated pH range of 7.16 to 8.20 in their study on monosex culture of Heterobranchus longifilis juveniles.

DO values in this study ranged from $5.3 \mathrm{mg} / \mathrm{l}$ to $6.12 \mathrm{mg} / \mathrm{l}$ for treatments TC $50, \mathrm{TC} 100$, TC 0 . These values were within range for freshwater fish culture as stated by Ovie and Adeniji (1990), who confirmed that fish do not grow well when dissolved oxygen remains at 4mg/l in another study, Robert et al., (2019a) also confirmed that at 4.40mg/l, fish deaths were not seen.

Conductivity values in this study ranged from $27.5 \mu \mathrm{S} / \mathrm{cm}$ to $52.5 \mu \mathrm{S} / \mathrm{cm}$ for treatments TC 50 , TC 100, TC 0 . These values were within range for freshwater fish culture. These values agree with Boyd, (1990) and Robert et al., (2019a) who stated freshwater conductivity ranges are from $212 \mu \mathrm{S} / \mathrm{cm}$ to $436 \mu \mathrm{S} / \mathrm{cm}$. Ayanwale et al., (2018) also indicated conductivity ranges of 100.60 to 338.00 $\mu \mathrm{S} / \mathrm{cm}$ for artificial fish culture.

Water temperature for this study stayed at $27.47^{\circ} \mathrm{c}$ throughout the treatments. This result was in agreement with Chakroff (1976) and Robert et al., (2019a) who indicated optimal water temperature range should be from $25^{\circ} \mathrm{C}$ to $31.36{ }^{\circ} \mathrm{c}$.

Air temperature for this study stayed at $24.35^{\circ} \mathrm{c}$ throughout the treatments. High water temperatures have otherwise been reported to range from $23^{\circ} \mathrm{c}$ to $25^{\circ} \mathrm{c}$. This range of water temperatures have been reported to be responsible for high mortality rates of fishes (Lee and Rinne, 1980; Bjorn and Reiser, 1991; Hodgson and Quinn, 2002).

\section{REFERENCES}

Afinowi, M.A. \& Marioghae, I. (1986). Summary of Aquaculture activities in Nigeria. In H. Powel (Eds.) Research priorities from African Aquaculture Report of a workshop, Dakar, Senegal, IDRC-MR, pp:149.

Benedict, O.O., Gabriel, U.I. \& Ezekiel, O.A. (2005). Effect of stocking size of the predatory African Catfish (Heterobranchus longifilis V.) on the growth performance of Nile Tilapia (Oreochromis niloticus L.) in pond culture. International Journal of Fisheries and Aquaculture. 1(3):38-43. In A.F. Yakubu, N.K. Nwogu, E.D. Olaji, O.O. Ajiboye, J.O. Apochi, T. E. Adams, E.E. Obule and E. Eke, (2014). A comparative study on growth performance and survival rate of Clarias gariepinus (Burchell, 1822) and Heterobranchus longifilis Valenciennes, 1840 under water recirculation system. Agriculture, Forestry and Fisheries Journal. 2014: 3 (1): 30-33.

Boyd, C.E. (1990a). Water quality in ponds for aquaculture. Alabama Agricultural Experiment Station, Auburn University, Auburn, Alabama. In T. B. Lawson(1994). Fundamentals of Aquacultural Engineering. pp. 18-19.

Boyd, C.E. \& Lichtkoppler, F. (1979). Water quality management in pond fish culture. International Centre for Aquaculture Agricultural Experiment Station, Auburn University, Auburn, Alabama. Research and Development series No 22. Project: AID/DSAN-G 0039.

Chandra, R. \& Jhan, N. (2010).The analysis of the length-weight relationship of Channa punctata with relative physico-chemical parameters. Journal of Expository Science. 2010; 1(5): 4-5.

Charkroff, M. (1976). Freshwater Fish Pond Culture and Management,Action /Peace Corps Programme and Training Journal, manual series number 1B. Volunteers in Technical Assistance (VITA). Publications manual series number 36E. 
Coulibaly, A., Ouattara, I. N., Kone, T., N’Douba, V., Snoeks, J., Goore Bi, G. \& Kouamelan, E. P. (2007). First results of floating cage culture of the African Catfish Heterobranchus longifilis. Valenciennes, 1840: Effect of stocking density on survival and growth rates. Universite de Cocody-Abidjan. Journal of Aquaculture. In A.F. Yakubu, N.K. Nwogu, E.D. Olaji, O.O. Ajiboye, J.O. Apochi, T. E. Adams, E.E. Obule and E. Eke, (2014). A comparative study on growth performance and survival rate of Clarias gariepinus (Burchell, 1822) and Heterobranchus longifilis Valenciennes, 1840 under water recirculation system. Agriculture, Forestry and Fisheries Journal. 2014: 3 (1): 30-33.

Engle, C.R. \& Valderrama, D. (2001). Effect of stocking density on production characteristics, coasts and risk of producing fingerlings channel catfish. North American Journal of Aquaculture, 63: 201-207. In A.F. Yakubu, N.K. Nwogu, E.D. Olaji, O.O. Ajiboye, J.O. Apochi, T. E. Adams, E.E. Obule and E. Eke, (2014).A comparative study on growth performance and survival rate of Clarias gariepinus (Burchell, 1822) and Heterobranchus longifilis Valenciennes, 1840 under water recirculation system. Agriculture, Forestry and Fisheries Journal. 2014: 3 (1): 30-33.

Gamal, O.E., Nabil, A.I., \& Mohammed, Y.A.Y. (2008). Influence of fertilizers' types and stocking density on water quality and growth performance of Nile Tilapia-African Catfish in Polyculture system, $8^{\text {th }}$ International Symposium on Tilapia in Aquaculture, p.157.

Hodgson, S. \& Quinn, T. (2002). The timing of adult sockeye salmon migration into fresh water: adaptations by populations to prevailing thermal regimes. Canadian Journal of Zoology 80(3): 542-555.

Khairenizam, M.Z. \& Norma - Rashid, Y. (2002). Length - Weight relationship of mudskippers ( Gobidae: Oxudercinae) in the coastal areas of Sclangor, Malaysia International Centre for living Aquatic Resources Management, World Fish Centre Quarterly, 25: 20-22.

Krol, J., Glogowski, J., Demska-zakes, K. \& Hliwa, P. (2006). Quality of semen and histological analysis of testes in Eurasian Perch Perca fluviatilis L. during a spawning period. Chechoslovakia Journal of Animal Science, 51 , 2006 (5): $220-226$.

Lee, R.M. \& Rinne, J.N. (1980). Critical thermal maxima of five trout species in the southwestern United States. Transactions of the American Fisheries Society 109 (6),632-635.

Lloyd, R. (1961). Effect of Dissolved Oxygen Concentrations on the Toxicity of Several Poisons to Rainbow Trout (Salmon Gairdnerii Richardson). Journal of Experimental Biology 38: 447-455.

Marjani, M.,Jamill, S., Mostafavi, P.G., Ramin, M. \& Mashinchian, A. (2009). Influence of $17 \alpha-$ methyltestosterone on mascularization and growth in Tilapia (Oreochromis mossambicus) Journal of Fisheries and Aquatic Science, 4:7174.

Mocintosh, D.J., Varghese, T.J. \& Satyanarayana-Rao, G.P. (1985). Rao hormonal sex reversal of wild spawned tilapia in India. Journal of Fish Biology, 28: 87-94. 
Mubarik, M.S., Ahmed, I., Mateen, A. \& Iqbal T. (2011). $17 \alpha$ - methyltestosterone induced mascularization and its effect on growth and meat quality of Cyprinus carpio. International Journal of Agriculture and Biology ., 13: 971-975.

Ndome, C.B., Ekwu, A.O. \& Ateb, A.A. (2011). Effect of Feeding Frequency on Feed Consumption, Growth and Feed Conversion of Clarias gariepinus Male and Heterobranchus longifilis Female Hybrids. American-Eurasian Journal of Scientific Research 6 (1):06-12-2011.

Nwokoye, C.O., Nwuba, L.A. \& Eyo, J.E. (2007). Induced propagation of African Clariid Catfish Heterobranchus bidorsalis (Geoffrey Saint Hillarie 1809), using synthetic and homoplastic hormones. African Journal of Biotechnology 6(23): 2687-2693.

Oguntuase ,B.G. \& Adebayo, O.T. (2014). Sperm quality and reproductive performance of male Clarias gariepinus induced with synthetic hormones (Ovatide and Ovaprim). International Journal of Fisheries and Aquaculture, 6(1), 9-15.

Omitoyin, B.O., Ajani, E.K. \& Oyebola, O.O. (2011). Cold shocking at $5^{\circ} \mathrm{c}$ and $7^{\circ} \mathrm{c}$ in triploid production: effects on embryonic development, hatchability and fry performance in Clarias gariepinus. African Journal of Livestock Extension 9:13-18.

Ovie, S.I., \& Adeniji , H.A. (1990). Zooplankton culture in outdoor concrete tanks: The effect of local fertilizer on zooplankton population development. NIFFR Annual Report; 129-133.

Oyebola, O.O. \& Awodiran, M.O. (2015). Effect of spawning methods on fertilization, hatchability and fry size variation in Clarias gariepinus. Ife Journal of Science 17(2): 305-311.

Paschal, G.V.D., Nieuwegiessen, A.J.V., Johan, J. \& Johan, W.S. (2006). The effects of stocking density on welfare indicators in African catfish Clarias gariepinus (Burchell, 1822), AQUA Meeting, p.184. In A.F. Yakubu, N.K. Nwogu, E.D. Olaji, O.O. Ajiboye, J.O. Apochi, T. E. Adams, E.E. Obule and E. Eke, (2014). A comparative study on growth performance and survival rate of Clarias gariepinus (Burchell, 1822) and Heterobranchus longifilis Valenciennes, 1840 under water recirculation system. Agriculture, Forestry and Fisheries Journal. 2014: 3 (1): 30-33.

Robert, E.A., Yisa A.T., Tsadu S.M. (2019a). Growth performance and survival of monosex cultured Heterobranchus longifilis juveniles in concrete flow-through and stagnant water systems. Scientific Research Journal (SCIRJ). 7(2):43-65. ISSN: 2201-2796.

Sveier, H., Raae, A.J. \& Lied, E. (2000). Growth and protein turnover in Atlantic salmon (Salmo salar L.); the effect of dietary protein level and protein particle size. Aquaculture, 185: 101-120.

TBoujard, L., Labbe, L., \& Auperin, B. (2002). Feeding behavior , energy expenditure and growth of rainbow trout in relation to stocking density and food accessibility. Aquaculture Research, 33: 1233-1242. In A.F. Yakubu, N.K. Nwogu, E.D. Olaji, O.O. Ajiboye, J.O. Apochi, T. E. Adams, E.E. Obule and E. Eke, (2014). A comparative study on growth 
performance and survival rate of Clarias gariepinus (Burchell, 1822) and Heterobranchus longifilis Valenciennes, 1840 under water recirculation system. Agriculture, Forestry and Fisheries Journal. 2014: 3 (1): 30-33.

Viveen, W.J.A.R., Richter, C.J.J., Van Oordt, P.E.W.G., Janssen, J.A.L. \& Huisman, E.A. (1985). Practical Manual for the culture of the African Catfish (Clarias gariepinus). Directorate General for International Technical Corporation. The Hague, $93 \mathrm{pp}$. 